\title{
The social evolution of distant othering and the racialized other
}

\section{Abstract}

Critical race theory holds that racism, and by extension othering, is embedded within every aspect of American society. We agree with critical race theorists, but elaborate further, that othering in some form or another, has existed since the Stone Age, and evolves with the uneven expansion of social complexity and the emergence of hierarchies. Othering, has always been important for reproducing differences and inequalities within society. We highlight the socially "distant other" to instruct the ways we discern modern racism, and how it has evolved from its past iterations. The argument we hope to convey is that at its core, distant othering involves the fear of a perceived threat to the existing social order and with the emergence of global capitalism, the racialized version of othering is violent, a violence that that becomes particularly intense when rates of profit collapse (i.e. economic crises) and/or when group-statuses are threatened. The theoretical perspective we use is institutional materialism and we take a historical, long-term sociocultural evolution approach. We detail othering in the Stone Age, which centers around kinship distance, the transition from small scale societies to the Bronze Age, as well as othering in the Axial Age and the modern era. The modern version of othering, which centers on nationality, race and ethnicity, is coupled with global capitalism and plays out in particularly cruel ways. 


\section{The social evolution of distant othering and the racialized other}

\section{“Othering"}

Critical race theory holds one tenet to be true: that racism, and by extension othering, is embedded within every aspect of American society. We agree, but elaborate further, that othering in some form or another, has existed since the Stone Age, and evolves with the uneven expansion of social complexity and the emergence of hierarchies. Othering is based on socially constructed boundaries between the individual self and others as well as between groups - "us" and "them," in-groups and out-groups. We maintain that all human societies have organized identities around othering which includes different forms of stereotyping. And othering, has always been important for reproducing differences and inequalities within society.

In this paper we highlight the socially "distant other" to instruct the ways that we discern modern racism, and how it has evolved from its past iterations. At its core, distant othering involves the fear of a perceived threat to the existing social order. We examine the social evolution of the self, the other, and the forms taken in distinguishing between in-groups and out-groups and how this has changed over the course of human sociocultural evolution. ${ }^{1}$ Finally, we argue that with the emergence of global capitalism, the racialized version of othering is violent, a violence that that becomes particularly intense when rates of profit collapses (i.e. economic crises) and/or when group-status is threatened.

To study long-term, large scale evolution of organizational structures, institutions and the ideational changes that relate to the scale changes that have emerged since the Stone Age, we employ concepts from sociology and anthropology -disciplines that have examined in great detail,

\footnotetext{
${ }^{1}$ In using the term 'evolution', we mean long-term patterned change in social structures, especially the development of complex divisions of labor and hierarchy. We do not mean biological evolution, which is a very different topic, and neither do we mean "progress."
} 
the behavior of human individuals and groups. Therefore, we make use of the literature on the self as an institution (Mead 1934), identity theory, the connection between the self and others, role theory and Simmel's important concept of social distance (Simmel 1955, 1971). Further, our work is motivated by critical race theory (Crenshaw 2002; Delgado and Stefancic 2000) and more contemporary ideas on othering (Fields and Fields 2012; Guillaumin 1995; Mbembe 2019; Morrison 2017; Powell 2015; Quijano 2000), with an emphasis on, racialized othering.

Our theoretical perspective is institutional materialism and we study sociocultural evolution using the comparative world-systems perspective (Chase-Dunn and Lerro 2013). Immanuel Wallerstein $(1987,2017)$ as well as Edward Said (1978) and others, contend that racism is structurally connected with the core/periphery hierarchy of the modern capitalist world-system. Thus, we are very interested in the rise of racialization of the other, as it relates to hierarchy and power in the contemporary global system.

Sociocultural evolution has involved the invention of institutions that allow larger, more complex and more hierarchical human polities to function. Accompanying these long-term changes have been the emergence of more complex selves as well as larger and more abstract collective identities and solidarities. And these have been related to the restructuring of how we conceive of the internal and external other. The racialization of the other, i.e. racism, is, and must be, understood as socially constructed but it is not uniform in the ways it is conceived, and the ways it operates and is deployed by its purveyors (Gillborn 2018). It works differently in different modern polities, and it has taken different forms as human polities got larger and more complex.

Both Georg Simmel (1955) and Lewis Coser (1956) noted that conflict is an important form of socialization because in-group solidarity is related to, and mainly produced by, competition and conflict between groups. What "they" are depends on, and is related to, what "we" 
are and what "I" am. This is tied to status characteristics - beliefs about social categories that are consensually held by members of a society (Berger, Cohen, and Zelditch Jr. 1972), and are assigned to maintain group positions. These stereotypes that structure expectations about the behavior and evaluations of others, especially strangers.

Many status characteristics are ranked. Examples are wealth, income, education, gender, ethnicity and race. In this approach, racial categories are socially constructed, and the content and evaluation of these categories differ across societies and change over time within a society. Profiling is an example of how status characteristics affect expectations and might induce conflict. Furthermore, expectations about behavior often stimulate feelings such as comfort, fear and anger. Still, status characteristics, both individual and group, vary in the degree of consensus about them. They are often contested, and change over time. Reactive movements, sometimes violent, often emerge during the periods in which status characteristics are changing, particularly from those who think their privileges and resources are threated. Like Coser and Simmel, other scholars (Blumer 1958; Fields and Fields 2012) have asserted that othering has less to do with a particular set of feelings one member of a group has for another but rather, it is primarily about the position a group holds in society and the preservation of power positions.

A thesis on the role of conflict in sociocultural evolution comes from Samuel Bowles (2008) who notes that humans have evolved in competing groups and that the bigger and more combative groups eliminated the smaller ones, leading to the rapid emergence of larger groups as well as more warlike and murderous behavior. As noted by the Kruglanski et al. (2019), environmental scarcities that increase competition over resources can affect group cohesion and attitudes toward the other, leading to violent conflicts, but narratives and networks that reinforce differences are just as important. Environmental changes brought on by carbon emissions, 
stratospheric ozone depletion, depletion of good agricultural land, forests, fisheries and degradation of water supplies underlie violent intergroup conflict. Wendy Barnaby (2009) argues, that while it is often the case that conflict arises over resource scarcity, that is not the rule. The key issue is to understand that how the other is defined, whether it be through ethnic or religious imaginaries. These ideological elements are crucial determinants that structure the emergence, reproduction and intensity of conflicts.

In most cases, violence among small scale societies involves neighboring groups who are considered enemies and viewed through negative stereotypes - subhuman, immoral, disgusting. There was usually very little contact with groups who were not immediate neighbors, but some polities specialized in long-distance raiding and slave-taking. Examples range from the Haida and Lekwiltok of the Northwest Coast of North America to the Vikings, some Turkic groups, and the East African Arabs. These slavers always developed highly negative stereotypes about the people they victimized, in order to justify the cruelty of their activities. Otherwise, truly distant peoples were little considered, as they were often thought of as too weird to be truly human. They were imagined and depicted as bizarre beings much like those described in the writings of Pliny the Elder — dog-headed people, people whose faces are on their chests, and so on; or even the descriptions in the Chinese Classic of Mountains and Seas (2000), which apparently represented shamanistic visions of spirit lands.

Georg Simmel's (1971) concept of social distance was developed to help understand the situation of ethnic minorities within a society. His "stranger", lives within the local society but is seen as socially distant from most of the community members. This distance is primarily due to the stranger's origins, which is thought of as vastly different from the majority of community members. Social distance does not equate physical distance as the stranger is simply "perceived" 
as outside the group despite being in constant contact with the group. This means that who is deemed a stranger is not immutable. The stranger is in the group but not of the group.

There is no question that intolerance, prejudice, and othering are deeply inscribed in human societies (Kteily, Hodson, and Bruneau 2016). Unlike the distant other in some of the anthropological texts who is seen as non-human or weird, Castano (2012) has argued that the hated or despised other is normally thought of as human, but not worthy of consideration or of good treatment. This is primarily due to a lack of empathy for the other. Castano introduces the term "infrahumanization" for this, a phenomenon that, many genocide and prejudice scholars now embrace. Poor treatment of marginalized groups is usually justified by the belief that they are not fully human - not people, even non-human. Hence the emergence of language comparing othered people to animals or with the language typically reserved for animals.

For Thomas Hobbes (1651) and John Locke (1689), humans in their natural state were true "savages" (Latin homo sylvaticus, "person of the forest"). They were warlike, isolated in small groups, nomadic, and without laws, private property, or moral orders. These authors located their "savages" not amongst themselves but in "America," despite having many reports that indigenous Americans were not even remotely like their stereotypes.

Hobbes and Locke's notions about the savages were based on old ideas about the "wild man," that persisted in medieval Europe. The idea of the "savage" in America created a foundation for the despicable treatment of Indigenous people by the settlers of the New World and Australia. The most striking exception in the early exploration period is the very strong and enlightened advocacy of the Spanish humanists, notably Bartolome de Las Casas (1552), but also Diego Duran, Bernardino de Sahagun and others. They successfully argued that Native Americans were 
fully human, had souls, could not be killed at will, and had rights (including property) that had to be respected. They argued less successfully that Native people should not be enslaved.

Jean-Jacques Rousseau later argued for a less negative view of "savages." Contrary to persistent myth, he never used the phrase "noble savage," nor did he think savages were particularly noble. His savage was in fact the chimpanzee (1755), which was, indeed, hairy, nonlinguistic, forest-dwelling, somewhat social, and powerful, like the imagined European wild man. Rousseau's portrayal is suggestive of Charles Darwin's description of the natives of Tierra del Fuego: "I could not have believed how wide was the difference between savage and civilized man: it is greater than between a wild and domesticated animal, inasmuch as in man there is a greater power of improvement" (Darwin 1959:X).

The othering of a group of people can evolve from descriptions such as Darwin's to more castigatory forms of racialized control. For example, even before the expansion of capitalism in its global form, Elizabethan Englishmen viewed Africans as an "other," unlike anything they had seen before. Winthrop D. Jordan (1968) contended that the concept of "blackness" (initially based on obsessions about the skin color of Africans) were "loaded with intense meaning" (malignant, baneful, disastrous, having dark or deadly purposes etc.) that placed Africans as dangerous and inferior in comparison with Englishmen.

This preoccupation with assigned meanings and presumptions about the skin color of Black people was compounded by the supposed lack of religion in Africa. Unlike their efforts to convert indigenous Americans, Europeans did not proselytize in Africa until the late eighteenth century (Jordan 1968). This led to the general view that Africans were "a people of beastly living, without a God..." (Jordan 1968:24). African heathenism was often linked explicitly with barbarity and blackness as one aspect of their many "defects." 
Religious wars spun out of control in Europe in the $16^{\text {th }}$ and $17^{\text {th }}$ centuries, leading to exhaustion that led in turn to religious tolerance in a few countries (Te Brake 2017). The slave trade, already huge and a cornerstone of global capitalism, vastly increased in the $18^{\text {th }}$ century. Rapid colonial expansion led to genocides from Australia and the Americas to west China (the Dzungarian genocide of the mid- $18^{\text {th }}$ century) and Siberia. It is with settler colonialism and the slave trade that we see a significant rise in racism and distant othering, and in the idea that distant people are savages or otherwise inferior. George Stocking (1968) and Lee D. Baker (1998) have demonstrated that the rise of racism can be traced to its connections with exploitative labor relations and land conquest.

Like Stocking (1968) and Baker (1998), Eric Williams (1944) argued that the root of slavery in the Americas was economics and not the racialized othering of Black Africans. Williams insisted that the slavery of Black Africans was a solution, in certain historical contexts, of a labor problem and that slavery did not imply the inferiority of Black people. But, Jordan (1968) argues that the racialized othering of Black people by whites was dynamically joined with slavery. Englishmen already had a prejudice that informed their particular othering (the color black and all its connotations in Elizabethan England, the supposed lack of religion of Africans and all its implications, eating habits and other supposed "deviant" behavior etc.) (Davis 1984). Chattel slavery reinforced those prejudices producing a particularly vile and violent form of othering that permeated the institutions of American life. We argue that the violent racialization of Black people served a functional role in the rise of global capitalism and that violence worsens when capitalism is in crisis or when there is a perceived threat to the white supremacist social order. 


\section{Stone Age Othering}

As populations grew the annual migration routes of nomadic foragers shrank and eventually sedentism emerged as humans learned how to store enough food to remain longer in winter camps that became hamlets and then villages (Nassaney and Sassaman 1995). The transition from larger to smaller annual migration routes corresponded with the emergence of regional styles of tool kits, especially projectile points, that archaeologists interpret as evidence of the emergence of regional ethnic identities.

An important aspect of this transition is the institutional forms of interaction within these small-scale societies. Marshall Sahlins' (1972) depiction of "Stone Age Economics" provides an important insight into the nature of othering in world-systems composed of small polities. Social labor is mobilized as kin obligations. Kinship is a consensual normative moral order - a set of categories that specify the obligations and non-obligations of each individual vis-à-vis others. The economy is institutionalized as a set of sharing and reciprocity obligations in which kinship

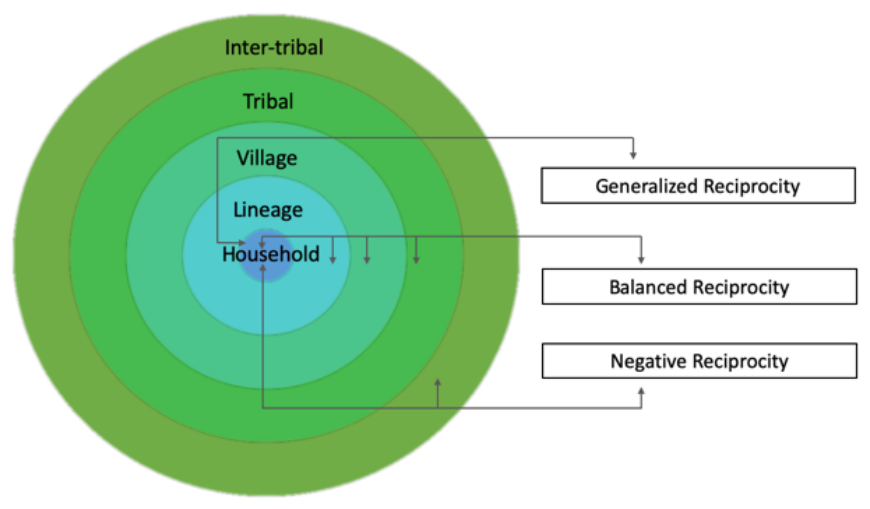

Figure 1. Reciprocity and Kinship Residential Sectors. Source: Sahlins 1972: 199: Figure 5,1 distance is the key structure.

Sharing ("generalized reciprocity") does not calculate who gets what, so there is no quantification of debt. All the interactors have the right to take what they need and the failure to reciprocate does not result in the giver ceasing to give. In Sahlins' model of the "domestic mode of production" this "generalized reciprocity" occurs among very close kin, usually within the household (see Figure 1). The household is at the center with respect to kinship distance and forms of exchange. As we move out 
from the center to the lineage, and village sectors, the type of interaction becomes "balanced reciprocity" in which a gift is expected to be repaid. Beyond the village sector is the tribal sector, and beyond that is the intertribal sector where "negative reciprocity" is in operation. "Negative reciprocity" is a relationship in which theft is legitimate. There is no expectation of repayment. One is supposed to get as much as one can and give as little.

This model of institutional types of interaction is germane to understanding the ways in which individual and collective identities operate within small-scale societies and is both similar and different from the ways in which modern individual and collective identities and the other operate. The self has much obligations to socially close others (say, from their lineage) but obligations decrease with social distance until they become "negative reciprocity" involving either no obligation or active enmity. Stone Age distant othering is entirely defined by kinship distance.

Most small-scale societies had little inequality among lineages, so rank did not play a big role in structuring forms of interaction (Wengrow and Graeber 2018). We know from ethnographic studies of small-scale societies that genders were highly differentiated (Herdt 2006; Myers 1986; Ward and Edelstein 2013), though some had third-gender men who lived socially as women and had important jobs (Meyer-Cook 2008) ${ }^{2}$. But gender differentiation was not usually accompanied by much gender hierarchy. The identities of men and women were constructed as different, but women usually had important participation in group decision-making.

Animistic religious beliefs and the idea that non-humans and what we think of as inanimate objects, such as trees or mountains, are powerful "others," were common in small-scale societies (Tylor 1873). Shamanic specialists could become possessed by spirits and take the form of a bird or an animal or insect; and, every person had the capability to use spiritual allies to do harm or

\footnotetext{
${ }^{2}$ For in-depth analyses of third gender "two-spirits" see Beverly Chiñas (1997) and Alfredo Mirandé (2016).
} 
good. The possibility of witchcraft often undermined trust between close kin and co-villagers and cross-cut the outer edges of reciprocity in ways that reduced the ability of polities to mobilize solidary groups for warfare with one another (Bean 1974).

Increased group cohesion was sometimes formed through the practice of polygyny, including sororal polygyny ${ }^{3}$ (Chisholm and Burbank 1991), in ethnographically-known small scale societies, but sororal polygyny also constrained opportunities for headmen to construct interpolity alliances through marriage (Walker and Bailey 2014). Sovereign polities usually included one or a few villages. Beyond that, alliances were formed, based on participation in ritual feasting, dancing, gambling, reciprocal gift-giving and support in warfare (Vayda 1967). Wars were of two kinds: line wars or raiding.

Line wars were ritual/ceremonial encounters meant to resolve violations of collective territorial claims to gathering or hunting sites or other transgressions. In this case, the two sides would line up and throw spears at one another until someone was injured. The issue was generally resolved without much bloodshed (Gat 1999). Line wars tended to occur between polities that shared a language or that had ties by inter-marriage. On the other hand, in a raid, a village of the enemy was attacked, usually under the cover of night and every effort was made to massacre all the residents, with the exception of women, who were sometimes abducted (Gat 1999). Raid wars occurred primarily between polities that did not share a language and between which there were few intermarriages. The difference between line wars and raid wars suggests a crucial distinction between types of negative reciprocity. There is a big gap between indifference, and a level of enmity that justifies extermination. Indifference is distant othering. Enmity is very distant othering.

\footnotetext{
${ }^{3}$ Sororal polygyny involves an obligation to marry a wife's sister, which reduces the ability to form another alliance by intermarriage.
} 
Trade among small-scale societies is usually organized as gift-giving between heads of physically adjacent polities. Goods may travel long distances by being traded from group to group (down-the-line trade) but there are no long distance "merchants" bringing goods from afar. Distant othering sometimes involves stories about giants, demons, wild men (sasquatch or big foot) and old women who steal children and eat them (Suttles 1987:Chapter 6). Therefore, long-distance trade or procurement treks are feared to be extremely dangerous. Still, there were Simmelian strangers within the group, such as witches and those believed to be possessed by bad spirits.

An intermediate form of distant othering occurred in some small-scale societies when war captives were taken to be traded. The pre-contact Pacific Northwest of North America featured a large, hierarchical system in which the core polities had enough economic power to motivate the peripheral polities to employ warfare against one another for the purpose of capturing. Within the coastal polities (Haida, Kwatkiutl, Tlingit), hereditary chiefs maintained their status and power in a system of competitive feasting and gift-giving known as the potlach. These maritime polities were hunter-gatherers with access to valuable coastal food resources and who had enough economic power to purchase war captives from peripheral polities. The peripheral polities raided one another and sold captives in exchange for food and other valuables. The coastal polities had ranked lineages, slaves, and a very strong ideology of superior birth. Between five and twenty-five percent of the population of the coastal polities were slaves (Mitchell and Donald 1985). This was an atypical, but interesting, kind of core/periphery hierarchy among small-scale polities.

The Pacific Northwest shows the existence of economic imperialism in the absence of pronounced commodification, which does have implications for distant othering. While a proto-money (dentalium shells) was used as a medium of exchange, most exchange took the form of reciprocal gift-giving carried out by village heads. The down-the-line trade relocated war 
captives from distant slave raiders to the maritime core polities. But slaves and their children in the core polities usually became integrated, after a period, into the local kinship system by marriage and adoption (Patterson 1982). The integration of former slaves into the kin networks of the core societies implies a lack of distant othering similar to the racism of the modern capitalist worldsystem.

\section{The transition from small-scale societies}

Human settlements and polities grew, and socially constructed inequalities increased, at first in chiefdoms and then in early states. Big man and chiefdom polities evolved hierarchical forms of kinship in which lineages were ranked and class distinctions between commoners and sacred chiefs became institutionalized. Chiefs were members of lineages that were thought to be more closely descended from founding ancestors and to have special powers over the forces of the universe. Commoners had no legitimate independent claim to land and were thought to be only very distantly related to revered ancestors -an expansion of social distancing within societies. This was the birth of class society and it had significant consequences for the social construction of selves as well as distant others. Land and nature, no longer viewed as living spirits to which we must all submit, became regarded as the property of chiefs, inherited from their revered ancestors. Topophilia, with creation myths, which sometimes involved stories about ancestor coming out of local caves or geographically dramatic islands, were reconstructed as legitimation of power. This provided the basis for chiefs to convert reciprocity into centralized redistribution.

To have access to land for horticulture, commoners had to turn over a portion of their production to chiefs. The chiefs had obligations to the commoners, but the basis of unequal exchange was laid in the institutionalization of land ownership. And this was maintained by 
ideological constructions and by the exercise of institutionalized coercion. Chiefs imposed taboos to regulate resource use, and commoners who violated taboos were punished and sometimes killed. This was the beginning of the tributary mode of accumulation. ${ }^{4}$ But the remaining aspects of reciprocity attached to kinship obligations were a limitation on how large and centralized a chiefdom could be. This limitation was eventually transformed by the emergence of states in which the connection between power and kinship was largely separated, allowing priests and kings to autonomously control resources that were not subject to reciprocity. This enabled an even more hierarchical form of within-polity othering to emerge between commoners and aristocrats. Commoners were born to carry water and to hew wood. Aristocrats were born to rule.

\section{Bronze Age Othering}

Early states and cities first emerged in Bronze Age Mesopotamia in a region that already had paramount chiefdoms and the beginnings of irrigated agriculture. States are different from chiefdoms in that they have specialized institutions of regional control and the central power of the state is less organized around kinship. The form this took in Mesopotamian cities was a theocracy in which the temple was the state, and both the city residents and the priests were held to be slaves of the city god. The temple economy, which tithed and redistributed food and other goods, was on top of a kin-based economy based on sharing and reciprocity (Zagarell 1986). Kinship identities were still important, but a new identity had been added -slaves of the city god.

The first city to emerge was Uruk, but copycat cities emerged nearby on the flood plain of the Tigris and the Euphrates rivers, each constructed around a different city god. The city was the god and the state and a collective identity emerged on the basis of membership in an urban

\footnotetext{
${ }^{4}$ The tributary modes of accumulation used (and use) institutionalized coercion organized as legal control over property to extract rent, taxes and tribute from direct producers.
} 
community. Hence "citizenship" was as much about obligations to the temple, as it was about rights to participate in rituals and feasting. The temple owned property within, and agricultural land outside the city. These early states shared a Sumerian language and culture, but earlier Semitic-speaking migrants from surrounding regions also became residents, forming an ethnically distinct class of Simmelian strangers -- workers and servants (Yoffee 1991).

Cuneiform writing was invented in the Mesopotamian states to keep records regarding transactions in the temple. Moreover, the mental labor and abstract cognition involved in writing allowed for the ruling class to construct a view of the elite self that was distinctly different from that of direct producers, i.e. workers and servants (Chase-Dunn and Lerro 2013:148-71). A differentiated hierarchy emerged as social complexity increased.

Since the Mesopotamian flood plain contained little stone, and timber soon became scarce, the cities organized long-distance trading with adjacent regions, trading grain and pottery for copper, tin, precious stones and other goods. Uruk (the first city) organized what was probably the first colonial empire in which citizens of Uruk moved to quarters in distant settlements to carry out this trade (Algaze 1993). This was an early example of what Philip Curtin (1984) called a "trade diaspora" -trusted co-citizens or co-religionists take up residence in distant locations to carry out long-distance trade. Distant othering now included trusted co-religionists or co-citizens, the beginning of internationalism.

Non-citizens and non-co-religionists are not likely to observe the norm of reciprocity. Therefore, oftentimes, trade diasporas emerged in a situation wherein trade is profitable but trust and other institutional mechanisms that ensure payment of debts are not in place because of negative reciprocity. When minority ethnic groups specialized in long-distance trading they became Simmel's stranger, an internal socially distant other. Still, But trade diasporas lost their 
function when trust and institutionalized mechanisms emerged that allow direct trade with distant peoples - what Phillip Curtin called a "trade ecumene" (1984). This can occur through the institutionalization of money and markets, which allowed strangers to interact with, and trust one another despite knowing little about each other. Thus, the emergence of the commodification of goods and of wealth, decreased reliance on cultural consensus and facilitated multicultural interdependence. This also helped to institutionalize the concept of cross-cultural "humanity."

While most human societies think of themselves as the center of the universe, premised on the belief and conviction of cultural superiority vis-à-vis distant others, Bronze Age Mesopotamia saw the birth of a set of othering distinctions organized around ideas of civilization, barbarism and savagery. This is exemplified in the "Epic of Gilgamesh." Gilgamesh was a King of Uruk in a period in which competing city-states were emerging and the palace, home of the battle king, had emerged as an important locus of power contending with the temple (Chase-Dunn and Lerro 2013:131-47). The epic reflects the competitive relationship between the temple and the palace. Gilgamesh refused to become the consort of Inanna, a powerful priestess, and got important support from his "wildman" friend Enkidu, with whom he was able to fight and defeat powerful enemies. The Enkidu figure is an interesting instance of the idea of the "noble savage" and the exotification of the other. This is a recurring trope in all systems that have a core/periphery hierarchy. Peripheral peoples are often seen as inferior and sometimes as threatening "savages," but sometimes they are depicted as noble, living in a pure state of nature. Distant othering in core/periphery hierarchies includes both versions, at least since the Bronze Age, and they contend with one another (Anderson 2005; Bartra 1994).

Bronze Age Mesopotamia also developed a transmogrifying, almost animalizing version of the distant other. During this period, the accumulation of stored wealth was greater than ever 
before, which meant that nomads from the periphery had opportunities to take from the wealthy in the core. Incursions by nomads from the periphery were an important phenomenon that influenced the development of agrarian empires and cities in several world regions (Thompson 2021). For example, the Amorite tribes were nomadic pastoralists who came into Mesopotamia from the deserts of the northwest. In order to prevent incursions from the Amorites, the Ur III dynasty constructed a Great Wall of Mesopotamia across the northern edge of the core region (Postgate 1992:43). This led to an ideology of "subhuman barbarism" very similar to the modern racialized form of othering. The Mesopotamians did not generally vilify different ethnic groups (Cooper 1983), but they did view the Gutians as "savage," "beastlike imbeciles," and the Amorites as "curious primitives," "less horrible" if every bit as threatening militarily, than the Guti. Cooper's characterization $^{5}$ of the Sumerian beliefs about the Gutians and the Amorites demonstrates that racialized othering is not a uniquely modern phenomenon. Of note here is that the very negative distant othering in Mesopotamia seems to have emerged regarding peoples who were perceived as threatening to the core societies. In this case Wallerstein's hypothesis of a connection between core/periphery hierarchy and racism is borne out, as well as our theory regarding the correlation between perceived threat and othering.

\section{Iron Age, Axial Age, and The Rise of World Religions}

Compared to Stone Age small scale societies, cities and empires are much more complex in terms of their organizational structures, their forms of governance and the networks (particularly their

\footnotetext{
${ }^{5}$ See Zakiyyah Iman Jackson's work, Becoming Human. While not specifically addressing this time period, her work is pertinent to the discourse on imparting "animal qualities" to groups of humans. In discussing the conflation of Black humans with animals, in Enlightenment discourse, she argues that the logic for this transmogrification is based on the "violent imposition and appropriation... of black(ened) humanity in the interest of plasticizing that very humanity, whereby "the animal" is one, but not the only, form blackness is thought to encompass" (2020:3). Her goal, is not necessarily to rehabilitate this view of Blackness, but rather to bring to light alternative conceptions of being and the non-human that are produced by "blackened people."
} 
political military, and information networks). Empires rose because states developed the military capability to conquer adjacent regions and the governance capability to extract resources from the conquered regions. The law, bureaucracies, armies, transportation technologies and the emergence of commodified exchange using money facilitated the expansion of empires. Trading city-states emerged within the interstices of tributary empires, which encouraged commodity production and the expansion and intensification of trade networks (Chase-Dunn et al. 2015).

As such, the law emerged as written rules to extend over groups of people who did not share a single consensual moral order. This was functional for states that had conquered and incorporated culturally different groups. Normative order based on consensus continued to exist, but within a framework in which the state proclaimed and enforced laws. The state became an institution that could claim to rule over peoples that spoke different languages and who had different beliefs and different moral orders. And yet, authority in these situations, was frequently seen as illegitimate, raising the level of resistance and rebellion. People who had been conquered often saw themselves as subjected to illegitimate power. Religious social movements emerged in colonized regions that produced new forms of individual and collective identities and expanded moral orders to catch up with the scale of legal orders. ${ }^{6}$

The phenomenon of peripheral and semiperipheral marcher states (peripheral or semiperipheral polities that conquer existing core states to create empires) (Inoue et al. 2016) and their role in the formation of these larger empires is related to issues of solidarity and internal othering. As empires got larger, inequalities within states became more extreme, with distinct groups within the state actively seeking to protect their status within society and with that, more elaborate and complex ideas of the other. Individual peripheral and semiperipheral marcher lords

\footnotetext{
${ }^{6}$ Such an example would be the religious Almoravid movement which arose, between 1042 and 1054 among the Sanhaja Berbers and led to the fall of the Ghana Empire (Boahen 1966).
} 
were often alpha males who engendered strong solidarity with, and amongst, their warriors. In the more urbanized agrarian empires of the period, the elites were socially distant from their soldiers and were not as effective in inspiring trust. But trust was increased and expanded by the rise of a global moral order through world religions ${ }^{7}$ that produced new interethnic moral communities.

The rise of the world religions during and after the Axial Age is an example of how social movements can propel the evolution of forms of governance. World religions in our sense separate the moral order from kinship, allowing for, and encouraging the inclusion of non-kin into the circle of protection. This is the expansion of human rights beyond the bounds of kinship and the expansion of what Peter Turchin (2016) calls "Ultrasociety" - altruistic behavior among non-kin. In small systems, distant non-kin are sometimes viewed as non-humans, not worthy of positive reciprocity. The question of who the humans are and who are "not-the-humans" is important in all cultures. When interaction networks and polities expanded, important debates occurred as to whether newly encountered peoples had souls, or not. The rise of what we currently call humanity as a social construction was a long, slow, back-and-forth, and uneven process that continues in the current struggle over citizenship.

The moral order promoted by world religions during the Axial Age was important for the construction of legitimate authority (Turchin 2016:181-210). The king and even the emperor were supposed to also obey the religious commandments, at least in theory. This gave the conquered a claim to membership in the moral community and provided a basis for claims against the authorities if they were violating the rules. Early Christianity can be viewed as a social movement

\footnotetext{
${ }^{7}$ The term "world religions" in everyday discourse simply means organized religions with large numbers of adherents in the contemporary world. Here we use it in a narrower sense to mean religions that combine universalistic claims with a proselyting mission that is expansive across kinship and language groups.
} 
(Blasi 1988; Mitchell, Young, and Bowie 2006; Stark 1996) that later served to legitimate a multiethnic Roman empire. ${ }^{8}$ Christ and his followers emerged in the context of a powerful Roman colonialism in which the colonized peoples were faced with overwhelming imperial force. Paul's mission to other colonized peoples and the delinking of salvation from ethnic origin was a recipe that allowed the movement to spread back to the poor peoples of the core. Christianity proved to be a fine motivator for later imperial projects such as the reconquest of Spain from the Moors and the conquest of Mesoamerica and the Andes (Padden 1970). It also served as a mechanism for the conquered to survive psychologically and to adapt to a world in which their indigenous lifeways were being radically transformed (Du Bois 2007:116).

The world religions developed important new forms of individualism and new kinds of collective solidarity that legitimated and facilitated larger empires and trade networks. These were important steps on the way to modern individualism and human rights and the evolution of othering.

The rise of monogamy also provides insight into the emerging global moral order and the evolution of distant othering, particularly in the Axial Age, which Karl Jaspers described as the period in which the moral and spiritual foundations of humanity were laid across the globe (1953). Walter Scheidel (2009) explains that while both "r" and the "K" reproductive strategies" were available to wealthy and powerful kings, "socially imposed universal monogamy" (SIUM) emerged as an aspect of the emerging global moral order. SIUM means that the king or emperor and the ruling class men can only have one wife. A purely historicist explanation would see the

\footnotetext{
${ }^{8}$ The power of the Christianity as a social and political movement, particularly during the late Middle Ages and the Reformation periods, is without doubt. Movements led by John Wyclif, Jan Hus and Thomas Müntzer, to name a few, were overtly sociopolitical (Encyclopedia of Religion 2020).

${ }^{9}$ In ecology the $\mathrm{r}$ strategy is pursued by weeds and most fish. They have a large number of offspring and only a few survive. The $\mathrm{K}$ strategy, involves having only a few offspring spending a large amount of resources on these as the bearers of the genetic future of the parents. Kings could do both by having a legitimate male heir with their primary wife (the queen) and by also having a lot of children with their concubines.
} 
predominance of SIUM, as a result of its adoption from the Romans and the Greeks by Europeans, who then imposed it on the rest of the world through colonialism and the rise of industrial capitalism. SIUM becomes the global moral order because it was imposed by the historically more powerful.

This is an accurate description of how SIUM became an element of the global moral order but we should also consider the effects of SIUM on the abilities of states to compete with one another. One argument is that monogamous marriage systems reduce competition among males for mates and decrease the number of unattached males who are an important group in the commission of violent crimes (Henrich, Boyd, and Richerson 2012). Monogamy decreases competition among men and lowers the crime rate and reduces the average male/female age difference within marriages, lowers the fertility rate, and reduces gender inequality and withinhousehold violence. ${ }^{10}$

We contend that SIUM facilitates greater solidarity between elites and their soldiers than does elite polygyny. Greater solidarity between classes provided a significant advantage in competition between states. Soldiers and citizens were more likely to identify with, and to support, leaders who appeared to follow the general moral rules regarding legitimate access to women. However, once monogamy became sanctified by the religion of the European West, it became part of the cultural package that European colonialism imposed on most of the rest of the world. So, part of the reason why the west was able to rise to global hegemony was due to having a moral order that reduced class antagonisms relative to those other contending civilizations that stuck with elite polygyny.

\footnotetext{
${ }^{10}$ See James S. Chisholm and Victoria K. Burbank's discussion of various “models” of polygyny (1991).
} 
The People's Republic of China was never a colony, but it made polygyny illegal in 1955 as a direct result of interaction with the West. Laws prohibiting polygyny were adopted in 1880 in Japan as part of the modernization effort that was the Meiji Restoration. Post-colonial India made polygyny illegal in 1953 (Henrich et al. 2012). Therefore, the global spread of monogamy was a matter of comparative advantage in warfare, imposition by the victors and emulation. This is relevant for our examination of othering because class relations within polities are part of othering and because the expansion of polities and the rise of the West has produced convergence on a global moral order in which cannibalism, ritual human sacrifice and polygyny are proscribed. This reduces the cultural differences upon which distant othering are usually based.

\section{Modernity, Science and the Modern Racialized Other}

Humanism, individualism and science are core ideologies of European modernity. ${ }^{11}$ Usually, these are understood to be products of the European Enlightenment but they have roots in the world religions of the Axial Age. World religions made a crucial step toward individualism when they separated kinship from the moral order and by erecting a moral community in which an individual can become a member by means of confession or self-declaration. Locating this power at the level of the individual person is the beginning of modern individualism. The rise of humanism also raises the issue of how human nature is conceived and where the boundaries between the human and the "not human" are constructed. These boundaries continued to evolve as polities and trade networks got larger but also served to foster a version of othering very different from that of smaller scale societies.

\footnotetext{
${ }^{11}$ We have qualified modernity here as specifically European modernity -the European phenomenon or process characterized by the development of scientific / technological rationality as well as the material objects of such process. See Anibal Quijano (2011).
} 
Nationalism is the most important collective identity in the contemporary world-system. Although ethnic identities have long emerged and ethnogenesis has been an important process since the Stone Age (Barth 1969; Hall 1984) nationalism is constructed in different ways, and its strength varies across countries and, over time, within countries. Civic nationalism is based on shared histories, traditions and customs, and can include various ethnic identities. Racial nationalism prioritizes beliefs about hereditary similarities and relies quite heavily on patriotism a sentiment that motivates cooperation and sacrifice for the nation and further entrenches the "us" from "them." As with other collective identities, rituals, symbols, songs, political constitutions and historical memories are important for producing and reproducing membership in the nation. The solidarity produced by nationalism is a vital component of the ability of countries to compete with one another, especially militarily, and so nationalism reinforces the global hierarchy.

The nation-state as a fundamental institution of political order, and by extension, nationalism, was an important concept that emerged out of modernity, and it was foundational for the emergence of modern colonialism and the rise of the Euro-centered capitalist world-system. Modernity gave rise to the structures of knowledge that helped codify as "objective," various social categories, such as, race, which facilitated the legitimation of the colonial project and the core/periphery hierarchy. The entire world population was subjected to these racial classifications through phrenological and/or physiognomical traits. This racialized othering is not based on an "emotional dislike" or "mental condition" such as hatred or malevolence for "Black" and "Brown" people. It is done to legitimize an existing socio-political world order. The creation of whiteness and "race science" was a distant othering process that constructed superior and inferior identities to justify genocide and exploitation. 
The rise of global capitalism in the long sixteenth century and the corresponding preeminence of Europe, and later, the United States was tied to this global racialized othering mainly by the trans-Atlantic slave trade (Cox 1959; Linebaugh and Rediker 2000; Robinson 1983; Williams 1944). The Atlantic slave trade arose to supply labor to the plantation economies of the European colonies in the Americas. Before this, slavery was a legal status that could be held by any person, not just Africans. The story of the incorporation of Africa into the expanding Europecentered world-system is relevant for our study of distant othering. Africa was an external arena, largely disconnected from the emerging modern European world-system in the long $16^{\text {th }}$ century. It became a source of labor, a place where captured Africans were bought and sold (Rodney 1970). This was a phase of parasitism that had severe consequences for African societies and produced a racialized core/periphery hierarchy. At the Berlin Conference on Africa in 1884 the European states parceled out colonies in Africa. Some have argued that this was Britain's way of trying to peacefully incorporate Germany into the world political economy in which Britain was still the hegemon (Wallerstein 1986). But, Europeans used it as a means to effectively establish full political and economic control over the African continent, and the relationship transitioned from plunder to parasitism.

Global capitalism relied on and required conquest, dispossession, exploitation and inequality. Racialized othering was functional for the production and reproduction of capitalism itself, with its most violent manifestations meted out on the racialized other in times of crises or perceived threat to the existing socio-economic and political hierarchies. For example, during Reconstruction in the U.S., whites tried every terrorizing technique possible, including murder, to disenfranchise and restrict Black people from social, political and economic freedom. In 1873 in Colfax, Louisiana, the struggle over the postwar government resulted in approximately 150 Black 
men being massacred by white men, mostly confederate soldiers and members of the Klu Klux Klan (KKK). By 1898, in Wilmington, North Carolina, the majority Black population, which was beginning to thrive, were resented by whites who refused to share political power with the Black citizens. After the November $10^{\text {th }}$ election, wherein a majority Black and Populist government was elected, a white mob led a coup and overthrew the government, destroyed printing presses, forced out the mayor, and attacked Black residents. They murdered approximately 300 Black people (Umfleet 2005) and sanctioned white supremacy in Wilmington and throughout the South, eclipsing the $14^{\text {th }}$ amendment (Edwards 1998). Whites terrorized citizens of an upwardly mobile Black community in Atlanta and on September 22, 1906, a false report of a white women being assaulted by Black women was used as an excuse for white men to violently beat, stab and murder Black people on sight. The unofficial death toll was approximately 100. In 1917, fear of Black men migrating to Northern Illinois for factory jobs spurred unfounded fears of Black men taking away the jobs of white men. July $1^{\text {st }}$ began a three-day riot of white people, including women, terrorizing Black people, savagely beating, stoning and murdering Black people. Thirty-nine, most likely more, Black people were killed and nine white people died.

The summer of 1919 was exceptionally bad for Black Americans. A confluence of the Great Migration (an exodus of Black people fleeing racial terror and Jim Crow in the South and heading North), a resurgence of the KKK, and a push by Black people for economic freedom led to what is known as the Red Summer. In Elain, Arkansas, where Blacks outnumbered whites 101 a demand for economic justice was rejected by the white minority. Whites, claiming a threat of insurrection by Blacks, responded by violently trying to maintain sharecropping, to prevent Blacks from unionizing, and maintain white economic and social dominance. They murdered over 200 Black people including children and tortured those they had arrested. In Washington D.C., a 22yr 
old Black veteran was killed, resulting in a race riot. The above events resulted from the interplay of racialized othering, capitalism and structural inequality. In discussing the Red Summer, Historian, Carroll "C.R." Gibbs noted, that it was "not just blind race hatred, but resentment of social gains the Black community made just after World War I. When we embraced the capitalist aesthetic, folks lynched us. When we showed we were prosperous, people burned down stores on the premise that we violated social codes and legal codes." This was clear with the massacres of Black people in Tulsa, Oklahoma in 1921 and again in Rosewood, Florida in 1923.

The current wave of anti-immigrant sentiment and racism can be understood as a reactionary response to neoliberal globalization that scapegoat's certain people, especially Black and Brown people, for problems caused by neoliberal capitalism. Distant othering is back in the form of white nationalism, "shithole countries," "terrorists," and "MS-13 animals." Alternative forms of progressive cosmopolitanism and multiculturalism are in retreat. We are entering a period of deglobalization corresponding with U.S. hegemonic decline. But the long and uneven upward trend toward the extension of citizenship and humanism is likely to continue after the current downturn has had its day.

While we are in the midst of a downturn in the expansion and institutionalization of human rights, the long-run evolutionary trend has been toward more inclusive solidarities and the extension of citizenship to the whole human species. And, although racism is still used by politicians to mobilize fear and support, we think that humanity will eventually construct a democratic and collectively rational global commonwealth in which conflicts can be resolved peacefully. 


\section{References}

Algaze, Guillermo. 1993. The Uruk World-System: The Dynamics of Expansion of Early Mesopotamian Civilization. Chicago: University of Chicago Press.

Anderson, Eugene N. 2005. "The Woodewose."

Anonymous. 2000. "Shan Hai Jing/The Classic of Mountains and Seas." in The Classic of Mountains and Seas, edited by A. Birrell. New York: Penguin.

Baker, Lee D. 1998. From Savage to Negro: Anthropology and the Construction of Race, 18961954. Berkeley: University of California Press.

Barnaby, W. 2009. “Do Nations Go to War over Water?” Nature 458:282-83.

Barth, Frederick. 1969. Ethnic Groups and Boundaries. Boston: Little Brown.

Bartra, Roger. 1994. Wild Men in the Looking Glass: The Mythic Origins of European Otherness. Ann Arbor: University of Michigan Press.

Bean, Lowell John. 1974. Mukat's People. Berkeley: University of California Press.

Berger, Joseph, Bernard P. Cohen, and Morris Zelditch Jr. 1972. "Status Characteristics and Social Interaction.” American Sociological Review 37(3):241-55.

Blasi, Augusto. 1988. "Identity and the Development of the Self." Pp. 129-39 in Self, Ego, and Identity: Integrative Approaches, edited by D. K. Lapsley and F. C. Power. New York: Springer.

Blumer, H. 1958. "Race Prejudice as a Sense of Group Position. Pacific Sociological Review 1: 3-7.” Pacific Sociological Review 1(1):3-7.

Boahen, Adu. 1966. Topics in West African History. Suffolk: The Chaucer Press Ltd.

Du Bois, Cora. 2007. The 1870 Ghost Dance. Lincoln: University of Nebraska Press.

Bourdieu, Pierre. 1979. La Distinction: Critique Sociale Du Jugement. Paris: Editions de Minuit. 
Bowles, Samuel. 2008. “Conflict: Altruism’s Midwife.” Nature 456(7220):326-27.

Te Brake, Wayne. 2017. Religious War and Religious Peace in Early Modern Europe. Cambridge: Cambridge University Press.

Bregman, Rutger. 2020. Humankind: A Hopeful History. English Tr. New York: Little, Brown and Company; Hacette Book Group.

Las Casas, Bartolomé de. 1552. A Short Account of the Destruction of the Indies. 1992nd ed. edited by N. Griffin. London: Penguin.

Castano, Emanuele. 2012. “Antisocial Behavior in Individuals and Groups.” Pp. 419-45 in The Oxford Handbook of Personality and Social Psychology, edited by K. Deaux and M. Snyder. New York: Oxford University Press.

Chase-Dunn, Christopher, Eugene N. Anderson, Hiroko Inoue, and Alexis Alvarez. 2015. The Evolution of Economic Institutions: City-States and Forms of Imperialism Since the Bronze Age. 79. Riverside.

Chase-Dunn, Christopher and Bruce Lerro. 2013. Social Change: Globalization from the Stone Age to the Present. New York: Routledge.

Chinas, Beverly. 1997. The Isthmus Zapotecs: A Matrifocal Culture of Mexico (Case Studies in Cultural Anthropology). New York: Publishers Harcourt Brace College.

Chisholm, James S. and Victoria K. Burbank. 1991. "Monogamy and Polygyny in Southeast Arnhem Land: Male Coercion and Female Choice.” Ethology and Sociobiology 12(4):291313.

Cooper, Jerrold S. 1983. The Curse of Agade. Baltimore: Johns Hopins University Press. Coser, Lewis. 1956. The Functions of Social Conflict. Glencoe, IL: Free Press. Cox, Oliver Cromwell. 1959. The Foundations of Capitalism. New York: Philosophical Library. 
Crenshaw, Kimberlé W. 2002. “The First Decade: Critical Reflections, or 'A Foot in the Closing Door."' UCLA Law Review 49:1343-72.

Curtin, Philip D. 1984. Cross-Cultural Trade in World History. Cambridge: Cambridge University Press.

Darwin, Charles. 1959. 1809-1882. The Voyage of the Beagle. Dent: Dutton.

Davis, David Brion. 1984. Slavery and Human Progress. Oxford: Oxford University Press.

Delgado, Richard and Jean Stefancic. 2000. “Introduction.” in Critical Race Theory: The Cutting Edge, edited by R. Delgado and J. Stefancic. Philadelphia: Temple University Press.

Edwards, Laura F. 1998. “Captives of Wilmington: The Riot and Historical Memories of Political Conflict, 1865-1898.” Pp. 113-42 in Democracy Betrayed: The Wilmington Race Riot of 1898 and Its Legacy, edited by D. S. Cecelski and T. B. Tyson. Chapel Hill: University of North Carolina Press.

Encyclopedia of Religion. 2020. "Christian Social Movements.” Encyclopedia.Com.

Fields, Karen E. and Barbara J. Fields. 2012. Racecraft: The Soul of Inequality in American Life. Brooklyn: Verso.

Fry, Douglas P. 2013. War, Peace, and Human Nature: The Convergence of Evolutionary and Cultural Views. edited by D. P. Fry. New York: Oxford University Press.

Gat, Azar. 1999. “The Pattern of Fighting in Simple, Small-Scale, Prestate Socieities.” Journal of Anthropological Research 55(4):563-83.

Gillborn, David. 2018. "Heads I Win, Tails You Lose: Anti-Black Racism as Fluid, Relentless, Individual and Systemic.” Peabody Journal of Education 93(1):66-77.

Guillaumin, Colette. 1995. Racism, Sexism, Power and Ideology. London: Routledge.

Hall, Thomas D. 1984. "Lessons of Long-Term Social Change for Comparative and Historical 
Study of Ethnicity." Current Perspectives in Social Theory 5:121-44.

Henrich, Joseph, Robert Boyd, and Peter J. Richerson. 2012. "The Puzzle of Monogamous Marriage.” Philosophical Transactions Of The Royal Society B: Bioligical Sciences $367: 657-69$.

Herdt, Gilbert. 2006. The Sambia: Ritual, Sexuality, and Change in Papua New Guinea (Case Studies in Cultural Anthropology). New York: Holt Rinehart and Winston.

Hobbes, Thomas. 1651. Leviathan. New York: E.P. Dutton.

Inoue, Hiroko, Alexis Alvarez, Eugene N. Anderson, Kirk Lawrence, Teresa Neal, Dmytro Khutkyy, Sandor Nagy, Walter DeWinter, and Christopher Chase-Dunn. 2016. Comparing World-Systems: Empire Upsweeps and Non-Core Marcher States Since the Bronze Age. 56. Riverside.

Jackson, Zakiyyah Iman. 2020. Becoming Human: Matter and Meaning in an Antiblack World. New York: New York University Press.

Jaspers, Karl. 1953. Origin and Goal of History (Vom Ursprung Und Ziel Der Geschichte). London: Routledge \& Kegan Paul Ltd.

Jordan, Winthrop D. 1968. White Over Black: American Attitudes Toward the Negro, 15501812. Chapel Hill: University of North Carolina Press.

Kruglanski, Arie W., Jocelyn J. Bélanger, and Rohan Gunaratna. 2019. The Three Pillars of Radicalization: Needs, Narraties, and Networks. Oxford: Oxford University Press.

Kteily, Nour, Gordon Hodson, and Emile Bruneau. 2016. “They See Us as Less than Human: Metadehumanization Predicts Intergroup Conflict via Reciprocal Dehumanization.” Journal of Personality and Social Psychology 110(343-370).

Linebaugh, Peter and Markus Rediker. 2000. The Many-Headed Hydra: Sailors, Slaves, 
Commoners and the Hidden History of the Revolutionary Atlantic. Boston: Beacon Press. Locke, John. 1689. An Essay Concerning Human Understanding. edited by P. H. Nidditch. Oxford: Oxford University Press.

Mbembe, Achille. 2019. Necropolitics (Politiques de L'Inimitié). Vol. Durh. English Tr. Durham: Duke University Press.

Mead, George Herbert. 1934. "Mind, Self, and Society.” edited by C. W. Morris. Chicago: University of Chicago Press.

Meyer-Cook, Fiona. 2008. “Two-Spirit People: Traditional Pluralism and Human Rights.” Pp. 263-98 in Intersections: Cultures, Sexualités, et Genres, edited by S. Brotman and J. J. Levy. Quebec: University of Quebec Press.

Mirandé, Alfredo. 2016. "Hombres Mujeres: An Indigenous Third Gender." Men and Masculinities 19(4):384-409.

Mitchell, Donald and Leland Donald. 1985. "Some Economic Aspects of Tlingit, Haida and Tsimshian Slavery.” Research in Economic Anthropology 7:19-35.

Mitchell, Margaret M., Frances M. Young, and Kenneth Scott Bowie. 2006. The Cambridge History of Christianity: Vol 1, Origins to Constantine. edited by M. M. Mitchell, F. M. Young, and K. S. Bowie. Cambridge: Cambridge University Press.

Morrison, Toni. 2017. The Origin of Others. Cambridge, MA: Harvard University Press.

Myers, Fred R. 1986. "Reflections on a Meeting: Structure, Language, and the Polity in SmallScale Society." American Ethnologist 13(3):430-47.

Nassaney, Michael S. and Kenneth E. Sassaman. 1995. Native American Interactions: Multiscalar Analyses and Interpretations in the Eastern Woodlands. edited by M. S. Nassaney and K. E. Sassaman. Knoxville: University of Tennessee Press. 
Patterson, Orlando 1982 Slavery and Social Death. Cambridge, MA: Harvard University Press.

Padden, Richard. 1970. The Hummingbird and the Hawk: Conquest and Sovereignty in the Valley of Mexico, 1503-1541. Columbus: Ohio State University Press.

Pinker, Stephen. 2011. The Better Angels of Our Nature: Why Violence Has Declined. New York: Viking.

Postgate, J. N. 1992. Early Mesopotamia: Society and Economy at the Dawn of History. London: Routledge.

Powell, John a. 2015. Racing to Justice: Transforming Our Conceptions of Self and Other to Build an Inclusive Society. Bloomington: Indiana University Press.

Quijano, Aníbal. 2000. “Coloniality of Power and Eurocentrism in Latin America.” International Sociology 15(2):215-32.

Quijano, Aníbal. 2011. “The Paradoxes of Colonial/Modernity.” in Andre Gunder Frank and global development: visions, remembrances, and explorations, edited by P. Manning and B. K. Gills. New York: Routledge.

Robinson, Cedric. 1983. Black Marxism. London: Zed Press.

Rodney, Walter. 1970. A History of Upper Guinea Coast. Oxford: Oxford University Press.

Rousseau, Jean-Jaques. 1755. The First and Second Discourses and Essay on the Origin of Language. edited by V. Gourevitch. New York: Harper and Row.

Sahlins, Marshall. 1972. Stone Age Economics. Chicago: Aldine Publishing.

Said, Edward. 1978. Orientalism. New York: Vintage Books.

Scheidel, Walter. 2009. “A Peculia Institution? Greco-Roman Monogamy in Global Context." The History of the Family 14:280-91.

Simmel, Georg. 1955. Conflict and the Web of Group Affiliations. edited by K. Wolff. Glencoe, 


\section{IL: Free Press.}

Simmel, Georg. 1971. “The Stranger.” Pp. 143-50 in Georg Simmel: On Individuality and Social Forms, edited by D. Levine. Chicago: University of Chicago Press.

Stark, Rodney. 1996. The Rise of Christianity: A Sociologist Reconsiders History. Princeton: Princeton University Press.

Stocking, George. 1968. Race, Culture and Evolution. New York: Free Press.

Suttles, Wayne. 1987. Coast Salish Essays. Burnaby, British Columbia: Talon Books.

Thompson, William R. 2021 "'Incursions, Climate Change, and Early Globalization Patterns" in C. Chase-Dunn and Hiroko Inoue Systemic Boundaries. New York: Springer Verlag.

Turchin, Peter. 2016. Ultrasociety. Chaplin: Beresta Books.

Tylor, Edward B. 1873. “Animism.” Pp. 424-58 in Primitive Culture: Researches into the Development of Mythology, Philosophy, Religion, Language, Art, and Custom. Vol. 1, edited by E. B. Tylor. London: John Murray.

Umfleet, LeRae. 2005. 1898 Wilmington Race Riot Report.

Vayda, Andrew P. 1967. "Pomo Trade Feasts.” Pp. 494-500 in Tribal and Peasan Economies, edited by G. Dalton. Garden City: Natural History Press.

Walker, Robert S. and Drew H. Bailey. 2014. "Marrying Kin in Small-Scale Societies." American Journal of Human Biology 26:384-88.

Wallerstein, Immanuel. 1986. “The Three Stages of African Involvement in the WorldEconomy." in Africa and the Modern World, edited by I. Wallerstein. Trenton: Africa World Press.

Ward, Martha and Monica Edelstein. 2013. A World Full of Women. Boston: Pearson. 
Wengrow, David and David Graeber. 2018. “'Many Seasons Ago’: Slavery and Its Rejection Among Foragers On The Pacific Coast of North America.” American Anthropologist 120(10):237-49.

Williams, Eric. 1944. Capitalism and Slavery. Chapel Hill: University of North Carolina Press. Yoffee, Norman. 1991. Myths of the Archaic State: Evolution of the Earliest Cities, States, And Civilizations. Cambridge: Cambridge University Press.

Zagarell, Allen. 1986. "Trade, Women, Class, and Society in Ancient Western Asia.” Current Anthropology 27(5):415-30. 